\title{
Noble Metal Mineralization of the PGM Zone "C" of the East-Pana Layered Intrusion (Kola Peninsula)
}

\author{
O. Kazanov ${ }^{1}$, G. Logovskaya ${ }^{2(\bowtie)}$, and S. Korneev ${ }^{2}$ \\ ${ }^{1}$ Moscow Branch, FSUE “All-Russian Scientific-Research Institute of Mineral \\ Resources named after N.M. Fedorovsky”, Moscow, Russia \\ 2 Institute of Earth Science, Saint-Petersburg State University, \\ Saint-Petersburg, Russia \\ galkanuu@gmail.com
}

\begin{abstract}
The first study of the noble metal mineralization of the ore zone "C" of the East-Pana massif allowed to divide it into two types: early magmatic lowsulfide and late post-magmatic proper PGE associations.
\end{abstract}

Keywords: Fedorovo-Pana massif · East-Pana massif •

Stratiform mineralization · Platinum metal mineralization ·

Early magmatic and late post-magmatic platinum mineral associations

\section{Introduction}

Since the late 1980s in Kola Peninsula the platinum content, associated with ultramaficmafic magmatic complexes, has been studied. The Fedorovo-Pana early proterozoic layered intrusion of the peridotite-pyroxenite-gabbronorite formation has been recognized as the most promising object for discovering the industrial reserves of complex low sulfide PGE ores.

\section{Methods and Approaches}

The following research methods were used in the work: mineralogical description of sections of boreholes, study of samples of rocks, slides and polished sections, microprobe analysis of transparent polished thin sections from ore intervals, statistical treatment of chemical analysis data with program Statistica v.6.1 and then analysis and interpretation of results. These methods allowed to identify similarities and differences in the ore intervals and their mineralization, and to confirm the assumption of a various genesis of PGE mineralization in the ore zone "C" (Subbotin et al. 2012).

\section{Results and Discussion}

Based on the results of the study of ore mineralization within the ore zone " $\mathrm{C}$ ", two associations of noble metal minerals were identified. The first, early, magmatic association is represented by platinum and palladium sulfides (Fig. 1), native gold and 
silver, moncheite, kotulskite and ferroplatinum, forming inclusions in the magmatic major sulphide and rock-forming silicate minerals. There is a significant positive correlation dependence of $\mathrm{Pt}, \mathrm{Pd}, \mathrm{Au}$ with $\mathrm{Cu}, \mathrm{Ni}$ and $\mathrm{S}$. It is indicated in the Sungiyok area. Later, postmagmatic association is represented by sperrylite (Fig. 1), mertieite-I, mertieite-II, temagamite, telargpalite, stibiopalladinite and kotulskite, associated with secondary silicate and later sulphide (millerite) minerals. They develop along cracks and veins in the rock-forming and early sulfide minerals. For the second type, correlations with $\mathrm{Cu}$ are not characteristic, with $\mathrm{S}$ there is a significant negative correlation. This association is observed in the Chuarvy area. Both types of mineralization are characterized by abnormally low values of $\mathrm{Pd} / \mathrm{Pt}=0.1-1.7$ (Voytekhovich et al. 2008).
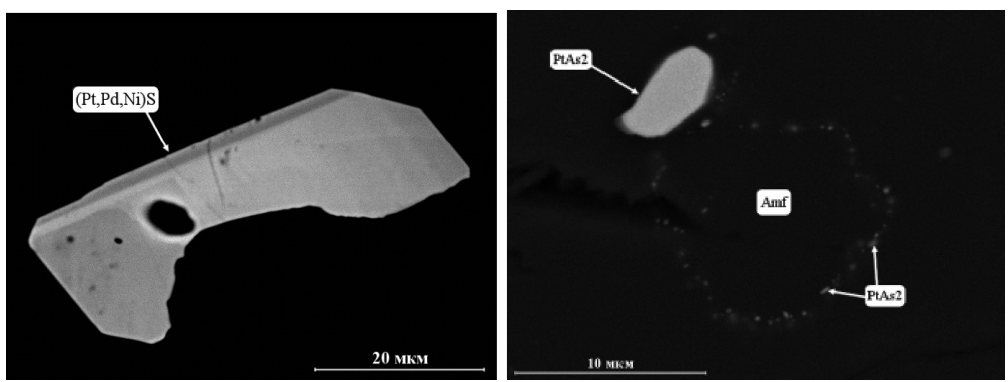

Fig. 1. Subhedral zonal aggregate of braggite $((\mathrm{Pt}, \mathrm{Pd}, \mathrm{Ni}) \mathrm{S}$ - early magmatic association of PGE mineralization (left); Spot edge around amphibole and micron streak of sperrylite $\left(\mathrm{PtAs}_{2}\right)$ postmagmatic, hydrothermal metasomatic association of PGE mineralization (on the right).

\section{Conclusions}

Thus, based on the identified features of the noble metal mineralization of the ore horizon "C", it can be divided into two types: low-sulfide platinum and properly platinum. The first type is characterized by a close relationship with sulfide minerals: noble metal minerals form intergrowths with the main sulphides, are included in rockforming silicate minerals. This type is typical for the ore horizons of the Sungiyok area. Minerals of noble metals are localized in cracks and streaks and are associated with minerals formed during the post-magmatic stage of intrusive evolution. This type is observed in Sunghiyok area and Chuarvy area.

Acknowledgements. Authors are grateful to V.V. Shilovskich for the research of minerals which carried out on the "Hitachi S-3400 N" scanning electron microscope at "Geomodel" Resource Centre of Saint-Petersburg State University. 


\section{References}

Subbotin VV, Korchagin AU, Savchenko EE (2012) Platinometal mineralization of the Fedorovo-Pana ore cluster: types of mineralization, mineral composition, genesis peculiarities. Vestnik Kola Sci Cent Russ Acad Sci 1:55-65

Voytekhovich VS, Kazanov OV, Kalinin AA (2008) Report on the results of prospecting and assessment work on platinum metal mineralization in the eastern part of the PanaTundrasmassif in 2006-2008. LLC Kola Mining and Geological Company, Apatity

Open Access This chapter is licensed under the terms of the Creative Commons Attribution 4.0 International License (http://creativecommons.org/licenses/by/4.0/), which permits use, sharing, adaptation, distribution and reproduction in any medium or format, as long as you give appropriate credit to the original author(s) and the source, provide a link to the Creative Commons license and indicate if changes were made.

The images or other third party material in this chapter are included in the chapter's Creative Commons license, unless indicated otherwise in a credit line to the material. If material is not included in the chapter's Creative Commons license and your intended use is not permitted by statutory regulation or exceeds the permitted use, you will need to obtain permission directly from the copyright holder.

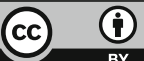

